\title{
MOZAMBIQUE'S 2014 ELECTIONS: A Repeat of Misconduct, Political Tension and Frelimo Dominance
}

\begin{abstract}
Adriano Nuvunga
Adriano Nuvunga is a lecturer in the Department of Political Science and Public Administration, Eduardo Mondlane University, Maputo, Mozambique e-mail: adrianonuvunga@gmail.com
\end{abstract}

\begin{abstract}
The cease-fire that ended the military hostilities between government and Renamo paved the way for Mozambique's fifth general elections on 14 October 2014. Frelimo consolidated its dominant position in an election underpinned by fraud and misconduct at the polling stations. There was an imbalance of power with Frelimo enjoying better organisation and patronage networks, control of the police and media, and secrecy in the National Electoral Commission (CNE), including altering results. This imbalance is shaped partly by the system of party dominance but also by the weakness of opposition parties who failed to use existing systems. Renamo's dispute of the electoral results and its endeavour to engage in dialogue with the government as a remedy for the alleged fraud reflects the inadequacy of Mozambique's elections as the mechanism for a political settlement. This sets the agenda for the next electoral cycle which, in procedural terms, will mirror previous elections.
\end{abstract}

Keywords: Frelimo, Renamo, MDM, elections, politics.

\section{POLITICS BEFORE THE ELECTIONS}

The electoral sequence in Mozambique is that local government elections take place the year before the general elections. Thus local government elections were held in November 2013, prior to the October 2014 general elections. Renamo, the former rebel movement and the biggest opposition party, boycotted the November 2013 local elections alleging that there were neither material nor legal conditions for these elections. As part of the boycott, Renamo did not take up its two seats in the National Electoral Commission (CNE). 
Despite this boycott, local elections were held amidst violent conflict. There were press reports of Renamo attacks on police officers, for example on 22 April 2013 there was a clash between the riot police (FIR) and Renamo fighters in Maringwe - the Renamo stronghold in the central province of Sofala - resulting in the death of 13 FIR officers (da Silva, 2011). On April 4, 2013 Renamo attacked a FIR camp in Muxungue killing four FIR officers (Frades, 2013) in an attempt to force Frelimo to make concessions on political arrangements.

The violence escalated with government forces bombing the Renamo central base in the Satungira hills in the Gorongosa district (Sofala province). Renamo stopped traffic on the only road linking the south to the rest of the country and even military convoys were unable to guarantee safe escort for civilian cars on this route. Hundreds of lives were lost, hundreds cars burnt and the fear of nationwide civil war threatened not only the electoral process but also the stability of the country. The electoral census took place during this conflict and the electoral authorities needed a special plan to register potential voters in the Save river and Muxungue regions, the areas affected by the conflict. The president of Renamo, Afonso Dhlakama, who was hiding in the Satungira hills, needed an extension of the registration period in order to register.

Though Frelimo enjoyed a two-thirds majority at the time, government and Renamo agreed to embark on a dialogue which began on 2 May 2013. Renamo had two major issues for discussion: a review of the electoral legislation, and parity of representation in the electoral bodies, namely the $\mathrm{CNE}$, the National Electoral Commission, and the Technical Secretariat for Electoral Administration (STAE). After 50 rounds of talks, government conceded on the electoral legislation with Parliament reviewing laws to accommodate Renamo demands. These included allowing Renamo to appoint deputy directors at all levels of the STAE, from the headquarters in Maputo to district level; and in addition the three main parties, namely Frelimo, Renamo and the MDM, had the right to appoint scrutineers (membros da mesa da assembleia de voto, or MMV) at each polling station, who were paid by the state. However, government did not concede on parity within the CNE.

In exchange, Renamo would hand in its military personnel, partly to be integrated into the national army and partly to be disarmed and reintegrated into civilian life. In the cease-fire agreement signed on 5 September 2014 between President Armando Guebuza and Dhlakama, an international team for the observation of the cessation of military hostilities (Equipa Militar de Observadores da Cessação das Hostilidades Militares, or EMOCHM), was established. EMOCHM was tasked with monitoring the integration of members of the Renamo militia, the so called residual forces, into the armed forces (FADM), the police, and civilian life, as well as dismantling and disarming the militia. While the electoral process moved 
swiftly as per the agreement signed by the two leaders, the work of EMOCHM was sloppy. Government accused Renamo of a lack of cooperation in handing in its lists of military personnel to be integrated into the national army, and Renamo insisted that a 'model of integration' was to be agreed on before doing so. The elections were held with these issues unresolved, which proved to be problematic for politics after the elections.

\section{CANDIDATE SELECTION AND THE ELECTORAL CAMPAIGN}

While Renamo's Afonso Dhlakama and the MDM's Daviz Simango emerged as the natural candidates for their respective parties in the presidential elections, Frelimo's Filipe Nyusi had to submit to tough primary elections within the party before he became Frelimo's presidential candidate. The then president of Frelimo and head of state, Armando Guebuza, was in his second and final term as set by the Constitution of the Republic; but he made a move towards a third term through a bill to amend the Constitution. This move was obstructed within Frelimo, a clear sign of Frelimo's political maturity and internal democratic processes. When this failed, president Guebuza attempted to promote a loyalist to replace him in order to retain some state control through which to maintain his business empire.

The preparation of this terrain was back-dated to the 2012 congress in Pemba, Cabo Delgado province. The composition of both the central committee ${ }^{1}$ and political commission ${ }^{2}$ was shaped to favour the political ambition of President Guebuza, with key historic members of Frelimo being sidelined from both (Nuvunga, 2014). In a departure from Frelimo tradition the statutes approved in the $10^{\text {th }}$ Congress of 2012 introduced two important changes. First, that the political commission should propose pre-candidates for presidential elections to stand for election before the central committee of the party. In the past, the central committee had elected the presidential candidate who was thereafter ratified by the political commission. Second was a more controversial innovation known as dois centros de poder, two centres of power, to distinguish between the head of state (even if he or she is the Frelimo candidate) and the president of the party.

1 The central committee deals with the business of the party between congresses. A powerful organ, it comprises 180 effective and 18 standby members who are responsible for the election of the party's president in cases where the president elected by congress has to be replaced; determines the composition of the political commission and elects its members; elects the members of the secretariat of the central committee; determines the composition and elects the members of the verification committee of the central committee, and ratifies the political commission's proposal of candidates for the presidency of the Republic.

2 Elected by the central committee, it consists of 15 to 21 members. The party president, the general secretary, and the secretary for verification are full members of the political commission. The head of Frelimo's parliamentary bench, the head of state, the speaker of Parliament and the prime minister, if elected by Frelimo, have permanent seats at the meetings but do not have the right to vote. 
Up until the $10^{\text {th }}$ congress and including the presidency of President Guebuza, the head of state, if elected by Frelimo, was also the president of the party. But according to the new statutes, the head of state and the president of the party would be two distinct roles. The head of state - who has a permanent seat at the meetings of the political commission but does not have the right to vote - is accountable to the political commission, headed by the president of the party, Armando Guebuza at the time. With this in place and the third-term option barred, the then secretary-general of the party unexpectedly announced that the political commission had met and proposed three candidates for primary elections in the party.

These three candidates were seen as President Guebuza's loyalists. So the process was bitterly criticised in the media, with opinion makers and Frelimo's own historic figures asking for more openness so that people other than these three nominees could have the chance to stand in the primaries. The three candidates canvassed the country seeking electoral support. Guebeza apparently favoured the prime-minister, Alberto Vaquina, and Jose Pacheco, minister for agriculture and rural development and head of the government delegation in talks with Renamo, who were considered likely to win the primaries.

In the end, the party opened up to other candidates which meant that former Prime Minister Luisa Diogo could contest the primaries as an independent. However he and the two apparently preferred candidates, namely Vaquina and Pacheco, all lost in the primary election held by the elective central committee on 1 March 2014. In the end, it was Luisa Diogo who forced a second round of the internal election. Filipe Nyusi, who had served as Armando Guebuza's minister for defence since 2008, was elected as Frelimo's presidential candidate in a democratic primary election. This was the first time that Frelimo had held primaries, as the previous two democratically elected Frelimo presidents had been appointed by the central committee and their candidacy ratified by the political commission.

As a candidate Filipe Nyusi ran an excellent, well-resourced campaign with a clear television message and massive motorcade rallies. His manifesto revolved around six points, but in his rallies and popular address he tended to emphasise the fourth point about the Promoção do Desenvolvimento Económico e Desenvolvimento Sustentável, Criação de Riqueza e Combate a Pobreza, that is economic and sustainable growth, wealth creation and the fight against poverty. In his showmicios, rallies, he also emphasised building infrastructure, ending unemployment, housing for the youth and expanding electric energy to rural areas. He promised to invest in technical and professional training for young people as the remedy for unemployment. Agriculture was a central theme in his campaign, together with national unity and peace, with his famous phrase 'na minha cabeça só cabe a paz, a paz, a paz', 'in my mind there is only space for peace, peace, peace'. He 
acknowledged that the separation of powers was not effective and that he would therefore work to achieve it, with particular focus on the independence of the judiciary and respect for the Constitution and ordinary laws. But there was a controversial issue: cars belonging to Frelimo members carried a sticker reading 'quem não é da Frelimo, o problema é dele', 'who is not a Frelimo supporter that's his/her problem'. This gave the impression that it was a problem not to belong to Frelimo, a clear sign of the political intolerance and arrogance characteristic of former liberation movements when in government.

Renamo's Afonso Dhlakama was in triumphal mode. First, he had resisted the bombardment by government forces of his central base in the Satungira hills. In this context President Guebuza took the blame for the military hostilities, not so much for initiating the aggression but for appearing to do little to prevent it from occurring. Second, these hostilities revitalised Renamo's dormant social bases and also the impoverished and excluded segments of the population. Third, the government had conceded to his demands regarding electoral legislation and improved transparency by politicising the electoral administration. Signing the cease-fire agreement with President Guebuza brought a breath of fresh air into a Renamo that was on the point of collapse after it had been soundly defeated by Frelimo in the 2009 election. So the military hostility between the government forces and Renamo returned Dhlakama to the centre of Mozambique's politics and political governance.

Although he had started the campaign some 15 days after the official date, Dhlakama was welcomed by huge crowds of supporters in all his rallies, including the three southern provinces of Inhambane, Gaza and Maputo, which are traditionally pro-Frelimo. While Frelimo clearly brought in supporters from different areas to the venues where key Frelimo cadres were rallying, Renamo lacked the logistical means to do that. Yet Dhlakama's rallies were surprisingly packed with people waiting for hours until he arrived. Key media houses and the independent TV station (STV), including the critical and specialised Mozambique Political Process Bulletin, emphasised the crowds at Dhlakama's rallies. His manifesto gravitated around the deepening of democracy, a government of social justice, and inclusivity. In his speeches he emphasised the rule of law, constitutionalism and multiparty democracy, and the separation of powers. He also pledged to put in place an efficient government which would serve the public interests. Contrary to campaigns in previous elections, he pledged that should there be a Renamo victory there would be no vengeance towards non-Renamo supporters, and all competent people would keep their jobs irrespective of their political affiliation. This was a very positive aspect that indicated a more politically mature Dhlakama. 
Daviz Simango's political and electoral success in the local elections in Beira in 2008 led to the formation of the MDM as a breakaway party from Renamo in 2009. Its non-transparent exclusion from contesting legislative elections in seven constituencies in 2009 gave it the status of martyr and victim in the informal concord between Frelimo and Renamo. Its victory in the 2011 municipal byelection in Quelimane (Zambezia province) and the good results it obtained in the 2013 local government elections gave the MDM the status of second party in Mozambique in the context of a collapsing Renamo. These results were mainly its victory in Beira, Nampula, Quelimane and Gurué, respectively the second, third and fourth cities in the country, and the near-victories in the capital Maputo and Matola municipalities The MDM was being projected as replacing Renamo in Mozambique's politics. The MDM and its presidential candidate also exhibited a triumphalist aura and apparently the 2014 elections were simply to confirm the ascension of the MDM as the second party in the country. But neither the MDM nor its president, the MDM's presidential candidate, had done any good political fieldwork between the 2009 and the 2014 election. Its eight members in Parliament had become highly urbanised and had little contact with their constituencies, and the MDM usually sided with Frelimo in Parliament.

The MDM also wanted to use the 2014 election to show that it was not just a Beira phenomenon, in reference to its home municipality. Historically, the MDM had originated in Beira after Simango was expelled from Renamo prior to the 2008 local elections and had stood as an independent candidate in the election. His victory as an independent built a momentum that he seized to form his own party. The fact that the MDM president is the mayor of Beira turned Beira into its hometown. His electoral manifesto focused on:

- public sector reform aimed mainly at reducing the excessive powers of the president

- separation of the party from the state

- zero tolerance to corruption

- emphasis on agriculture

- economic growth reflected in the daily life of the people

- improving the quality of education, and

- investing in the health sector.

However in 45 days of electoral campaign he focused more on criticising the government on the following grounds: mismanagement of the Mt 7 million intended for decentralised projects in the districts; dependency of the judiciary and legislative on the executive branch of government, particularly the head of state; youth unemployment; lack of investment in agriculture; and political intolerance towards the opposition. 


\section{ELECTORAL VIOLENCE, POLICE BEHAVIOUR AND THE USE OF STATE RESOURCES}

Three trends characterised the 45 days of electoral campaign. The first was electoral violence. Based on previous experiences prior to the electoral campaign, the electoral authorities and leaders of civil society, including religious leaders, used the media to make several appeals for a peaceful electoral campaign. In addition, political parties signed codes of electoral conduct agreeing to nonviolence, tolerance and mutual respect; but this proved to be easier said than done. The main features of electoral violence were:

- Clashes during campaign motorcades and rallies with physical aggression between supporters of the different political parties involving Frelimo, Renamo and the MDM. Sticks, katanas (machetes) and other sharp instruments were used in this electoral violence.

- Politically motivated groups attached to contending political parties made it difficult for their opposition to rally and organise gatherings. Provocation included occupying venues and routes previously communicated to the police as being prepared for a gathering by other political parties; throwing stones, or playing loud music, which made communication difficult. The opposition parties, mainly Renamo and the MDM, were the usual victims of these acts which were mainly in the southern province of Gaza, a Frelimo stronghold. Most of this violence happened in the Gaza and Nampula provinces.

- In Gaza, these events took place in Macia, Xai-Xai and Chokwe districts on 23 and 24 September. MDM's Daviz Simango was scheduled to campaign in Gaza, travelling by road from Maputo. The entry town into the province is Macia, where his motorcade was attacked by a sizeable group of people using sticks and stones, though few in the motorcade were injured. Unable to campaign in Macia, Simango moved to Xai-Xai, the capital of Gaza, where a large group greeted him with violence. His supporters were severely beaten up and some saw their homes burnt. On 24 September, Simango went to Chokwe, which had since 1994 been the centre of electoral violence against the opposition parties (Nuvunga \& Salih, 2010; Nuvunga, 2005). Simango had another violent reception, his supporters were beaten up again and electoral material destroyed, including vehicles belonging to his supporters. Similar incidents happened in Chibuto and Manjacaze, both in Gaza province. The police made some arrests in relation to the case, but oddly these were all MDM supporters (Mozambique Political Process Bulletin 2014a, p.1). 
In the northern province of Nampula on the $25^{\text {th }}$ September (a public holiday commemorating the day of Forças Armadas de Defesa de Moçambique, the Armed Forces for the Defence of Mozambique) MDM retaliated by taking a coffin covered by a Frelimo flag and a photograph of Filipe Nyusi, to Heroes Square. The riot police confiscated the coffin, and in the resultant hostility MDM supporters stoned the police, causing chaos and injuring civilians and a policeman. This led to the closure of the official ceremony at Heroes Square. The police had to use tear gas to control the situation (Mozambique Political Process Bulletin 2014b, p. 2).

- At the beginning of the campaign a group of $20 \mathrm{MDM}$ supporters were beaten up by Frelimo supporters and six were severely injured; a prelude to what happened to the MDM and Daviz Simango in Gaza.

- On 12 October, the final day of electoral campaign, Renamo and Frelimo clashed in Angoche, a Renamo stronghold in the northern province of Nampula. Both parties had planned to end the campaign in the densely populated area of Inguri, and as a result they clashed. Renamo supporters were armed with sticks, stones, and katanas and their members attacked 12 houses belonging to Frelimo district leaders. In retaliation, Frelimo supporters broke the windows of Renamo's district headquarters. Two people died and many more were injured (Mozambique Political Process Bulletin 2014d, p. 1).

- Renamo and Frelimo also clashed in Nampula on 12 and 13 October. With their leader Dhlakama in Nampula for the official closure of the campaign, Renamo supporters were reportedly clashing not only with Frelimo supporters, but also beating up anyone they found dressed in Frelimo campaign material. There were reports that some couples were forced to take off their Frelimo T-shirts and go home topless.

Since the onset of multiparty democracy in the country, Gaza has been a hostile, almost no-go territory for the opposition (Nuvunga, 2012). Initially it was opposed to Renamo and its leader, Afonso Dhlakama; but in the 2014 election it also turned against the MDM and its leader. This was not only because the political and electoral growth of MDM had turned it into a new Frelimo 'enemy'; but also the fact that Dhlakama's guard was armed with AK47s. Despite police intervention in Xai-Xai and the confiscation of some of these weapons, Renamo were still prepared to face attack. A new aspect was that Dhlakama had a hero's welcome in Xai-Xai, the Frelimo stronghold, but there was still not enough support to secure his party a single parliamentary seat from this constituency. 
Nationwide Frelimo tended to make it difficult for opposition parties and candidates to campaign, though to a lesser extent than in the past. Where the opposition enjoyed massive support, e.g. Nampula and Zambezia, they also targeted Frelimo supporters and Frelimo offices. This trend is part and parcel of Mozambique's two decades of democratic politics. Apparently Frelimo finds it hard to let the opposition campaign freely, possibly because it had liberated the land and the people, formed the nation and considered that it owned Mozambique. Veteran Frelimo politician and former minister of defence Alberto Chipande opined recently that Frelimo 'would lead the country for the next 50 years'.

Electoral violence is related to police behaviour and they are accused by opposition parties and candidates as being biased in favour of Frelimo. Their modus operandi includes giving Frelimo information about venues and routes to be used in opposition rallies. With this information, Frelimo groups either first occupy the venues and roads previously allocated to the opposition, or they prepare to stone opposition gatherings. Police are also accused of indifference or apathy when Frelimo groups attack opposition rallies and gatherings, and of being intransigent when faced with wrongdoing by opposition supporters. As a result, an overwhelming majority of the people arrested in connection with electoral crimes are supporters of opposition parties. This was confirmed in a press conference held on 30 September by the spokesperson of the General Command of the Police, General Pedro Cossa.

The police are also accused of deploying fewer policemen to protect opposition rallies and gatherings, and also of intimidating opposition supporters. For instance, in Nampula on the final day of the campaign (12 October), the police are reported to have fired tear gas to disperse the gathering waiting for Dhlakama at the muncipal stadium just before the start of the rally. The people disbanded and returned two hours later, only after Dhlakama had arrived. A policeman at the rally told journalists 'we had orders from the most senior commander to launch the tear gas. We just followed orders' (Mozambique Political Process Bulletin, 2014c, p. 1).

The third alarming trend in the electoral campaign is the illegal use of state resources. Frelimo controls the state and with it state resources, particularly the public buildings, state personnel and vehicles. After the 2013 local government elections, the opposition also controlled local government resources in the three main cities, namely Beira, Nampula and Quelimane. Historically, Frelimo used its control of the state to abuse these resources for electoral purposes; but now this is done not only by Frelimo but also by the opposition, although on a lesser scale. This use of state assets has diminished in comparison to previous general elections, but Frelimo had the unfair advantage of being the majority party in government. 
Not only were state vehicles and fuel deployed and used for the Frelimo electoral campaign, but high-ranking state personnel were also illegally coopted into Frelimo's electoral campaign. Indeed, President Guebuza indicated in his speech after the promulgation of the 2014 electoral results by the Constitutional Council on 30 December 2014, that he was impressed by the fact that ministers, national directors, and permanent secretaries had left the comfort of their homes in cities and had spent 45 days in rural villages campaigning for Frelimo. These high-level politicians and civil servants used not only state resources but also the powers of the state for Frelimo's benefit, meaning that Frelimo's much-vaunted party machinery is, in fact, state machinery. Public buildings carried Frelimo pamphlets, which is prohibited by law but this is not enforced. However, the opposition did the same in areas where they controlled the local government though realistically this was only the MDM, as Renamo had controlled no municipality since boycotting the 2013 local government election.

\section{ORGANISATIONAL PROBLEMS: POLLING STATONS AND TABULATION}

\section{Ballot-box stuffing}

As of 2004, ballot-box stuffing became a pattern in Mozambique's elections (Nuvunga, 2012; Rønning 2011; Nuvunga \& Salih, 2010; De Brito 2009; Hanlon \& Fox 2006; Nuvunga 2005). Its most common manifestations include extra physical (illegal) ballot papers being inserted in the ballot boxes, and changes to the results sheets, the edital in Portuguese. The Mozambique Political Process Bulletin estimates that in at least 680 polling stations (4\% of the total) there was ballot-box stuffing benefiting Frelimo.

Extra ballot papers in the box were noticed in Matola (Maputo province), Quelimane (Zambezia province), Beira and Dondo (Sofala province), and Chidenguele (Gaza province). According to the Mozambique Political Process Bulletin the scheme works as follows:

One member of the polling station staff (MMV) has the books of ballot papers which are handed out to each voter. With turnout around $50 \%$ they can be sure that not all ballots will be used, so when no one is looking, ballot papers are taken from further down in the book. These are then passed to previously identified Frelimo supporters when they are voting, and they deposit several ballots in the box. Often the ballot papers are pre-marked for Frelimo before being passed on to supporters.

(Mozambique Political Process Bulletin, 2014d, p. 8) 
The change of edital resulting in an increase in turnout clearly gave extra votes to Frelimo. This was first noticed in the 2013 local government elections, particularly in Gurue where the Constitutional Council had to invalidate the results and order a repeat of the election. This was despite the fact that the vote count system has an inbuilt mechanism to prevent fraud. After the partial vote count that takes place at the polling station, the editals are filled and signed by all members of the polling station and copies are given to political parties and observers and a copy is stamped at the entry of each polling station. Thereafter all ballots and the original copies of the edital are packed in a box which is then sealed. The next step is the transportation of the boxes to the district headquarters of the Technical Secretariat of Electoral Administration (STAE) for district tabulation. There have never been reports of violated boxes between the polling station and the STAE district headquarters, but editals do appear with changed results.

The implication is that the change of results takes places at STAE district headquarters. In the case of local government elections with few polling stations it was easy to compare the results produced by STAE district headquarters with those generated by civil society groups through parallel vote tabulation, and confirm that editals were manipulated. But it proved almost impossible to check the integrity of editals in a general election with 17,000 polling stations nationwide.

One intriguing aspect that appeared to be evidence of ballot-box stuffing is that in a sizeable number of polling stations there were more ballots for president than for Parliament. This is despite that fact that the ballot boxes for president and Parliament are side by side and 'observers and journalists almost never see a voter put a ballot in one box and not in the other (...) thus a difference between the two suggests extra votes have been added for president, either by changing the edital, or with extra ballot papers being inserted into the box just for president' (Mozambique Political Process Bulletin, 2014e, p. 8). Statistically, the Mozambique Political Process Bulletin reports that in $1.2 \%$ of polling stations the results show that between $10 \%$ and $90 \%$ of voters deposited ballots for the president and not for Parliament.

\section{Invalidating ballot papers}

This is a trend that began in the 2005 local government by-election in Mocimboa da Praia, in the northern province of Cabo Delgado (Nuvunga, 2012). Since then it has been observed in all subsequent elections, and always damaging to the opposition vote (Nuvunga, 2014). This is easy to observe since by law all invalid ballot papers (nulos) are sent to Maputo to be reconsidered by the National Electoral Commission and this requalification of nulos is open to media and observers. There it becomes clear which are really nulos and which were deliberately invalidated 
by people other than the voters. The nulos for the presidential election in 2004 was $2.7 \%$, increasing to $4.0 \%$ in the 2009 election.

Improvements in the law, e.g. no ink being allowed on the table at the time of the vote count, reduced the possibility of purposeful invalidation of votes; but there were still 3.2\% of nulos after requalification. According to the Mozambique Political Process Bulletin, more than 750 polling stations (4.5\% of the total) had an excessive number of invalid votes, which implies votes that were improperly invalidated, i.e. had an inked extract mark alongside an orderly expressed vote intention. As the Mozambique Political Process Bulletin indicates, it is illegal to falsely invalidate ballot papers, but the CNE declined to take any action to prosecute.

The people revalidating nulos were not instructed to separate out obvious groups of improperly invalidated ballot papers. This could have allowed prosecution, because all ballot papers now have the number of the polling station, and the fingerprints are sometimes clear enough to indicate which individual left the print.

(Mozambique Political Process Bulletin, 2014e, p. 9)

\section{Late opening}

Media reported that only four polling stations did not open, which is a significant improvement on previous elections. There were particular problems in Nampula, Nacala, Angoche (all in the northern province of Nampula) and Beira (in the central province of Sofala) where according to media reports some polling stations did not open until the afternoon. Polling stations are supposed to open at $7 \mathrm{am}$, failing which the problem must be solved by $11 \mathrm{am}$. Opening in the afternoon violates the electoral law. The Mozambique Political Process Bulletin estimates that in 450 polling stations (2.5\% of the total) turnout was improbably low, suggesting very late opening or other administrative problems. The problem was most notable in Zambézia, Nampula, Niassa, and Sofala, all known to support the opposition.

\section{Registration books}

Registration is problematic in Mozambique and problems with registration books prevented registered voters from exercising their franchise in past elections (Nuvunga, 2006). In 2014, observers and journalists reported that some polling stations had extra register books (cadernos) not on the official list of polling stations. These extra books are sometimes are called 'transfer lists' (lista de transferidos). Where there are two small register books and the total does not exceed 800 voters, 
the two books can be combined in a single polling station. This was done in some places, and the official list gives the numbers of both register books; but in some polling stations, the extra book was not on the list.

According to Mozambique Political Process Bulletin reports, the city of Tete suspended counting for a day because there were 234 editais (one edital per polling station) and only 178 polling stations. The official explanation from STAE was that some polling stations had more than one register book. In this instance MMVs incorrectly created a separate edital for each book instead of one for the whole polling station. Even so, that means 58 extra books, while the official list gives only 37. The Mozambique Political Process Bulletin estimates that up to 250 polling stations (1.4\%) had extra, unreported, register books.

\section{Problematic district tabulation}

Mozambique's vote count and tabulation have never been problem-free (Nuvunga, 2014; Nuvunga \& Salih, 2010; Nuvunga, 2005). Following the vote count at the polling station, the boxes are sent to the district and city election commissions (CDEs), which according to the law, add up the results from each polling station and produce one district edital. So there should be no further vote count. In the 2013 local government elections, the Conselho Constitucional, Constitutional Council (CC), invalidated the results of Gurue municipality (Zambezia province) after it confirmed that the district tabulation had been fraudulent. In 13 of 49 polling stations there were editais without the signature of the polling station president, or signed by the polling station president but with no stamp; editais from 15 polling stations had been altered, and in two polling stations editais had been written by the Zambézia CPE, not the polling station presidents. So district tabulation became a sensible part of the electoral process. After criticism from media and electoral observers, CNE agreed to allow for more transparency at the district tabulation, i.e. agreed allow journalists and observers to watch the district and provincial tabulation.

It soon became clear that the lack of transparency, which had been evident from the first democratic elections in 1994 until the 2013 local government elections, was used to conceal a disorganised district tabulation. In fact, as the Mozambique Political Process Bulletin indicates, observers found the first major problem was widespread confusion over the lack of instructions on how the district count should be handled. Clear rules are a central part of good governance for any electoral processes; so without guidance from STAE at national level, each CDE set up its own system. National media and the Mozambique Political Process Bulletin summarised the problems as the following: 
some used computers, some used pencil and paper, and some wrote on classroom blackboards. Some started as soon as they received their first editais while others waited until they received them all. Some started with data submitted by telephone and SMS and some waited for editais. Some did everything neatly while others had papers spread around the room and different people seemed to be following different systems. Some used special rooms, others were in smaller crowded rooms, and one was done in the district STAE director's office. Some allowed party representatives to check the final table and some did not. In some places it was impossible to check the data being input. Some CDEs, in violation of the law, refused to post the editais or give copies to observers and media.

\section{ELECTORAL RESULTS}

Provincial tabulation was peaceful, but CNE was highly divided with the final results approved by 10 votes to 7. Salomao Moyana, whose candidacy for the CNE was promoted by Renamo, was the only member from the opposition ranks who voted in favour of the final results, a vote that legitimated the results. Otherwise it would have been only Frelimo's members of CNE that would have voted in favour of the results. The opposition handed in protests to CNE which were approved by only 9 for and 8 against, meaning that Moyana this time sided with Renamo. The pro-opposition weekly paper, Canal de Moçambique, labeled Moyana a Judas Iscariot for having betrayed the opposition that supported his candidacy for CNE. Renamo and the MDM handed in appeals to the Constitutional Council, which were all rejected on procedural grounds, not on merit.

Renamo had in fact failed to follow the electoral law in relation to complaints. The requirement is that all complaints regarding tabulation and votes cast are to be made and submitted to competent people at the polling station. If not satisfactorily addressed, these complaints must then be submitted to the district courts of justice. Renamo failed to adhere to the electoral law that was amended at its request. Instead, Renamo collected all protests and submitted them to the $\mathrm{CNE}$ and subsequently to the Constitutional Council, which irrespective of the merit of the cause rejected the appeals in agreement with the electoral law. The results were promulgated by the Constitutional Council on the $29^{\text {th }}$ of December through Acórdão 21/CC/2014.

With a turnout of $49 \%$ (which is about 5.3 million voters) compared to $45 \%$ (4.4 million) in 2009, Frelimo and its candidate Filipe Jacinto Nyusi collected a comfortable victory, but lower than its record in the previous 2004 elections. Then Frelimo had gained a qualified majority in Parliament and its presidential 
candidate gained $75 \%$ of the vote. Table 1 below presents the presidential election in five elections.

Table 1

Presidential vote in five elections

\begin{tabular}{|c|c|c|c|c|c|c|c|c|c|c|}
\hline \multirow[t]{2}{*}{ Candidates } & \multicolumn{2}{|c|}{1994} & \multicolumn{2}{|c|}{1999} & \multicolumn{2}{|c|}{2004} & \multicolumn{2}{|c|}{2009} & \multicolumn{2}{|c|}{2014} \\
\hline & mn & $\begin{array}{c}\% \\
\text { of } \\
\text { valid }\end{array}$ & $\mathrm{mn}$ & $\begin{array}{c}\% \\
\text { of } \\
\text { valid }\end{array}$ & $\mathrm{mn}$ & $\begin{array}{c}\% \\
\text { of } \\
\text { valid }\end{array}$ & mn & $\begin{array}{c}\% \\
\text { of } \\
\text { valid }\end{array}$ & mn & $\begin{array}{c}\% \\
\text { of } \\
\text { valid }\end{array}$ \\
\hline Chissano & 2.6 & $53 \%$ & 2.3 & $52 \%$ & & & & & & \\
\hline Guebuza & & & & & 2.0 & $64 \%$ & 3.0 & $75 \%$ & & \\
\hline Nyusi & & & & & & & & & 2.8 & $57 \%$ \\
\hline Dhlakama & 1.7 & $34 \%$ & 2.1 & $48 \%$ & 1.0 & $32 \%$ & 0.6 & $16 \%$ & 1.8 & $37 \%$ \\
\hline Domingos & & & & & 0.1 & $3 \%$ & & & & \\
\hline Simango & & & & & & & 0.3 & $9 \%$ & 0.3 & $6 \%$ \\
\hline Others & 0.6 & $13 \%$ & & & 0.1 & $2 \%$ & & & & \\
\hline & & $\begin{array}{l}\% \text { of } \\
\text { total }\end{array}$ & & $\begin{array}{l}\% \text { of } \\
\text { total }\end{array}$ & & $\begin{array}{l}\% \text { of } \\
\text { total }\end{array}$ & & $\begin{array}{l}\% \text { of } \\
\text { total }\end{array}$ & & $\begin{array}{l}\% \text { of } \\
\text { total }\end{array}$ \\
\hline Nulos & 0.2 & $2.8 \%$ & 0.1 & $2.9 \%$ & 0.1 & $2.9 \%$ & 0.2 & $4 \%$ & 0.2 & $3.2 \%$ \\
\hline Brancos & 0.3 & $5.8 \%$ & 0.3 & $6.5 \%$ & 0.1 & $2.9 \%$ & 0.3 & $6 \%$ & 0.3 & $5.4 \%$ \\
\hline Total & 5.4 & & *5.3 & & 3.3 & & 4.4 & & 5.3 & \\
\hline Turnout & & $88 \%$ & & $74 \%$ & & $43 \%$ & & $45 \%$ & & $49 \%$ \\
\hline
\end{tabular}

Source: Mozambique Political Process Bulletin, 2014e, p. 8

The MDM doubled its share of parliamentary seats but this is still far below what the party expected to harvest. It is fair to say that the MDM and its candidate were defeated mainly by Renamo. With a disappointing vote of 0.3 million, MDM's Daviz Simango was the face of defeat in the 2014 elections. The dream of becoming the second political force in the country ended with harsh defeat and disappointment, whereas Renamo's Dhlakama tripled his electoral performance compared to 2009. Although he did not win the election he made significant political gains, particularly thrashing Simango of the breakaway MDM. The 2014 election revived the weakened Renamo and its president, who made a significant comeback to a position of strength in Mozambican politics. 
The results show that Frelimo retains its dominance in the four southern provinces and the northern province of Cabo Delgado, one of its strongholds. Dhlakama and Renamo gained majorities in three provinces, namely Nampula, Zambézia and Sofala. The two parties tied for place in three provinces, namely Tete, Manica and Niassa. The decisive factor for both the Nyusi and Frelimo victories is that in the four provinces that Frelimo dominates, both the party and the presidential candidate had a landslide victory. Victories by Renamo and Dhlakama have a small margin compared to those of Frelimo and its candidate.

Dhlakama disputed the electoral results on the grounds that they were fraudulent. MDM and Simango also disputed the electoral results on the same grounds but unlike Dhlakama, Simanto accepted the ruling of the Constitutional Council validating the electoral results generated by the National Electoral Commission. Neither Dhlakama nor Simango presented evidence for their claims. However, there was serious misconduct, including ballot-box stuffing and the invalidation of opposition ballot papers. The question is how serious the misconduct was and how much it impacted on the results. But the new electoral law, resulting from the amendments suggested by Renamo, was robust enough in theory to prevent misconduct like these from happening.

The revised electoral legislation gave a larger presence to the two main parties, namely Frelimo and Renamo, in both the National Electoral Commission and the Technical Secretariat for Electoral Administration at both central and district level. At the request of Renamo this also gave political parties - mainly the opposition parties - the right to name people who could check the system from within. This is the most manifest indication of an attempt to promote electoral transparency by politicising the electoral management bodies. The revised legislation introduced in 2014 offered the option for all three main parties, namely Frelimo, Renamo and the MDM, to submit names to the electoral management bodies. These would be added to the four polling station staff hired directly by the electoral management bodies, thus creating seven-member polling station teams. The function of these three party nominees was to perform regular polling station management duties, for which they would be paid by the electoral management bodies in the same way as the regular polling station staff. Although they could not submit complaints, they could give credibility to the electoral process by acting as the eyes and ears of their political parties; but the major problem was that opposition parties failed to recruit and submit enough people to be considered for this function.

Had the opposition parties succeeded in adequate recruitment, they could have collected all the editals nationwide and within hours after the closure of voting they could have had a realist projection of their electoral performance. Opposition parties claimed to have preferred to invest more in recruiting party delegates with a monitoring function who could make legal complaints; but the 
reality is that they failed to succeed in both cases, with neither scrutineers nor party delegates. Frelimo succeeded in placing their people as scrutineers in all polling stations but they neglected the party delegates. This might have been influenced by the fact that there is a guaranteed payment for scrutineers from the electoral management bodies, but payment for party delegates must come from the party. However, critics accuse Frelimo of neglecting this aspect because the system is seen to be skewed in favour of Frelimo.

It is noteworthy that despite the high rate of unemployment, guaranteed payment from the electoral management bodies was not enough of an incentive to attract people to function as scrutineers for opposition parties. However, opposition parties alleged that some of their candidate scrutineers were not awarded contracts by the electoral management bodies, and many of their candidates for the position of party delegate failed to be accredited by the same electoral management bodies. Indeed, the Carter Center observer mission (Carter Center, 2015) indicated that in 18\% of the 434 polling stations it observed, only Frelimo had both the party-nominated scrutineer and the party delegate. As far as the accreditation issue is concerned, the Carter Center observation mission estimates that the accreditation problem only affected some 1000 people (Carter Center, 2015). Taking into consideration all these problems, an aspect to be underlined is the lack of constructive collaboration between the two major opposition parties, Renamo and the MDM.

Evidence shows that in some polling stations where the opposition scrutineers were present they not only failed to prevent misconduct but also failed to collect evidence about where misconduct took place and where it was noted and reported by observers and media. In addition, as Mozambique Political Process Bulletin reports, '.. opposition members of STAE and district election commissions did not prevent problems with counts. Indeed, opposition party MMVs and election commission members sometimes signed manifestly incorrect results sheets (editais)' (Mozambique Political Process Bulletin 2014e, p. 10). Frelimo was accused of intimidating people in order to stop them from being recruited by the opposition. This is not new and is one of the privileges enjoyed by dominant parties, but the opposition also failed to make proper use of the new system for transparency based on politicising the electoral management bodies.

Civil society also designed initiatives aimed at checking the integrity of the electoral process. Focusing on the presidential election, a parallel sample tabulation (PVT) was carried out by EISA (Electoral Institute for Sustainable Democracy in Africa 2014) for the Electoral Observatory ${ }^{3}$. With a statistical sample of 1798 polling

3 Coalition of national civil society organisations including religion organisations dedicated to electoral observation. 
stations, about $10.6 \%$ of the total national polling stations, and based on official copies of the results sheets (editais) collected by independent national observers at the polling station, the PVT generated a result very close to the final official result. It projected 35\% for Dhlakama and the official result was 37\%; 57\% for Nyusi and the official result was 57\%; and $8 \%$ for Simango whose official result was $6 \%$. The Mozambique Political Process Bulletin rightly indicates that 'the closeness of the PVT to the final result suggests that there has been relatively little manipulation at intermediate levels, despite the confusion' (Mozambique Political Process Bulletin 2014e, p. 10) but does not say what happened at the polling stations. So the PVT may be confirming an unchecked fraud at the polling stations, augmented by the inability of the opposition parties to use the new system for transparency based on politicising the electoral management bodies.

Following from the above are three major problems underpinning Mozambique's 2014 election - problems which in reality underpinned all elections held in the country since the founding democratic election in 1994. First, fraud and misconduct at the polling stations which is seen as perpetrated by and benefiting Frelimo. Second, an imbalance of power, with Frelimo enjoying better organisation and patronage networks, and control of the police and media. Being the party of government allows Frelimo to abuse state resources for its electoral machinery. And third, secrecy in the CNE including changing results, which is shaped by a view that the electoral system should be party-based rather than neutral and impartial. Opposition thinking is that this would give them their own people on the inside to check what was happening; but this has happened only marginally because of the inability or unwillingness to train people to use their positions. Opposition officials in STAE allow misconduct to go unchallenged. All considered, it appears that Frelimo party dominance shapes the political economy within which elections take place. Not only does this effect the possibility opposition parties have to mobilise scrutineers and party delegates, but importantly their behaviour once in those positions.

\section{POLITICS AFTER THE ELECTIONS}

Politics after the elections had a sense of déjà vu, and a repetition of previous elections. There was a rejection of electoral results by Renamo, and political tension with Frelimo refusing any possibility of a post-electoral deal. Dhlakama returned to his position before the 2014 election, his hide-out in the Gorongosa hill, and conflict escalated. A few days after the election Dhlakama called a press conference and told journalists that the elections had not been free and fair, and because of these fraudulent results he was available to negotiate for a government of national unity. In parallel, Renamo had submitted a formal appeal for the 
Constitutional Council to invalidate the electoral results on the grounds of fraud.

Late in November Dhlakama called for a caretaker government consisting of competent people from both Renamo and Frelimo. A proposal along these lines was submitted to Parliament by Renamo but was dismissed by Frelimo. At the same time, government submitted to Parliament what Frelimo had refused to do for the previous two decades: a bill for the status of leader of the opposition. This was aimed at accommodating Dhlakama in the governance system but it was also a way to introduce and pass the controversial bill for the ex-president's and former MP's social provident fund.

Perceptibly unhappy with Frelimo's move Dhlakama initiated provincial rallies, mainly in those provinces where he had strong support, namely Zambezia, Nampula, Sofala, Manica and Niassa. It was in these highly crowded rallies that Dhlakama changed not only the tone of language but also the message. He told his followers that there would be a joint government consisting of Frelimo and Renamo. He said he was tired of seeing his electoral victories being stolen by Frelimo. He mentioned the problematic election in 1999, as well as those in 2004 and 2009. In December 2014 he told an overcrowded rally in Manica province that although he would not let Frelimo govern if it went on to form a government without the opposition, he would not use guns.

This hardening of the discourse came in the form of República Autónoma Centro e Norte de Moçambique, Central and Northern Autonomous Republic of Mozambique, which meant dividing the country at the Save River which links the south with the rest of the country. This is an old Renamo threat and to some extent it is built into the legacies of the liberation struggle and subsequent civil war. Renamo also boycotted the inauguration of Parliament and provincial assemblies. Although it was not the first time that Renamo had threatened not to take its seats in Parliament but had in the end done so, the then President elect, Filipe Nyusi, had agreed to meet the Renamo leader. There were two meetings where Dhlakama presented a new concept: autarquias provinciais, provincial autarchies, intended mainly to transform the provinces where Renamo obtained majority into provincial autarchies with a Renamo government. Historically, Renamo has since the onset of democratic politics demanded a shared government in the form of the right to appoint provincial governors in the provinces where it had a majority. This was a serious consideration in the negotiations following the problematic 1999 election, but it failed to materialise.

Renamo's new concept was presented as a bill in Parliament but Frelimo's political commission made it clear that it was not only against the meetings between Nyusi and Dhlakama but also against Renamo's bill for provincial autarchies. This was the first time that there had been a clear split between Frelimo and its head of state. The former president, Armando Guebuza, wanted 
to remain president of Frelimo with Nyusi as head of state. According to the new Frelimo statutes the head of state would be accountable to the Frelimo political commission headed by the party's president, Armando Guebuza. This scenario of dois centros de poder, two centres of power, came to an end in March, when the extraordinary meeting of the Central Committee acrimoniously told the powerful President Guebuza to relinquish office and allow Nyusi to take over the party leadership. This was a clear indicator of not only internal democracy within Frelimo but more importantly, the party's maturity. This made the young Nyusi not only the head of state but also the president of the party, setting a generational change within party leadership and the end of the rule of old combatants from the liberation struggle.

However, although President Nyusi kept his openness towards critics and the opposition there are signs that he was hardening his position towards Renamo and Dhlakama. His availability to meet Dhlakama evaporated and Frelimo has rejected the Renamo bill for provincial autarchies on the grounds of unconstitutionality. This bill resulted in the alleged fraud of the 2014 elections. If elections are proven fraudulent they have to be invalidated and repeated. It is legally problematic to call for a form of shared government as a remedy for fraudulent elections. Mozambique's proportional representation electoral system is a de facto winner-takes-all system, since although opposition parties have parliamentary representation - which gives them some state money proportional to their representation - they are not part of the network of patronage centered on the president-dominated government. The implication is that Dhlakama's 1.8 million votes count for nothing. So even if it is not proven, the fraud discourse is the only opportunity for the opposition, and particularly Dhlakama, to get something out of Frelimo, since Mozambique's elections fail to offer a mechanism for a political settlement.

Without progress in the talks between Renamo and the government, the first attacks were reported in the central province of Tete in June 2015, and Dhlakama escaped unhurt from an ambush in September 2015. In early October key negotiators escorted Dhlakama to Beira from where he was to travel to Maputo to meet President Nyusi. The following day his house was invaded by the army, and Dhlakama escaped back to Gorongosa. This was the start of the escalation of the conflict, but it was only in February 2016 that attacks were reported on the $\mathrm{N} 1$ road in the Muxungue region in the central province of Sofala. The aim was to block the communication between the south and the central part of the country. Cars were burnt and military convoys were needed to escort civilian cars. This continued until a final peace deal was reached in December 2016, which holds at the time of writing.

The formal talks were grounded and the two leaders reached a deal in 
informal talks that resulted in Nyusi travelling to meet Dhlakama in Gorongosa Hill. Before the formal talks were grounded they produced a key result, that of signing the agreement for a despartidarização da função pública, to depoliticise the civil service. If implemented this could be a major milestone in further democraticising the country. The main points of the agreement include the following:

- Civil servants are not obliged to undertake party political activities during their work time;

- Magistrates are forbidden to take part in any kind of political activities;

- Party and religious activities are forbidden in govermental institutions;

- Party cells are not allowed in govermental institutions;

- No obligatory salary deductions for political parties are allowed.

Three years after the 2014 election, Renamo still insists on appointing governors in the six provinces where it claims to have obtained a majority, but Frelimo succeeded in buying time for the next election. This has been the history of Frelimo's dominance of Mozambique's democratic politics and second republic: the five years after an election is spent addressing the claims from Renamo and mainly buying time for the next election. Decentralisation is again at the top of the agenda as a way of addressing power sharing. It is not yet clear how this point will be framed in the peace deal yet to be signed, and how it will implemented; but Renamo is inclined towards an agreement that will allow each party to appoint governors in those provinces where it obtained an electoral majority. All things considered the die is cast: addressing problems arising from the previous election and setting the course for the next electoral cycle where the same electoral problems will probably happen again.

\section{CONCLUSION}

The three major problems which underpinned Mozambique's 2014 election are characteristic of Mozambique since the founding democratic election in 1994. First, fraud and misconduct at the polling stations which is seen as perpetrated by and benefiting Frelimo. Second, there was an imbalance of power with Frelimo enjoying better organisation and patronage networks, and control of the police and media. Being the party of government allows Frelimo to abuse state resources for its electoral machinery. Third, secrecy in the $\mathrm{CNE}$, including altering results, is shaped by factors related to the opposition, namely a view that the electoral system should be party-based rather than neutral and impartial. Opposition thinking 
is that this would enable their own people on the inside to check procedures. However, this had only marginal success because of an inability or unwillingness to train scrutineers and party delegates to use their positions, and of opposition officials in STAE to allow misconduct to go unchallenged. All things considered, it appears that Frelimo party dominance shapes the political economy within which elections take place. This affects not only the possibility for the opposition parties to mobilise scrutineers and party delegates; but more importantly their behaviour once in those positions.

Mozambique's elections have suffered from mistrust both between the major parties, and by mainly opposition parties towards electoral management bodies, which they accuse of being biased towards Frelimo and its candidates. As a result of the 2014 peace deal, the electoral law had, in theory, inbuilt mechanisms for further transparency and fraud prevention: it allowed each of the three parties with parliamentary seats to appoint its own people as scrutineers, fully paid by the electoral management bodies. So each party had to recruit 17000 scrutineers. Although these scrutineers could not make formal complaints, they could check the system from within. This was the most manifest indication of an attempt to promote electoral transparency through politicising the electoral management bodies. While Frelimo managed to recruit its share of scrutineers, the two major opposition parties failed to do so. In most cases they failed to recruit not only scrutineers but also party delegates whose responsibility is to monitor the process and make formal complaints. So the opposition parties failed to use the new system of transparency to check the system from within, which was evident later in the poorly substantiated claims by opposition parties, in particular Renamo.

As far as the electoral process is concerned, Renamo's Afonso Dhlakama and the MDM's Daviz Simango emerged as their respective parties' candidates for the presidential elections. However, two important events took place within Frelimo which not only evidenced substantive internal democracy within Frelimo but also maturity of the party. Firstly, Frelimo prevented the then party leader and head of state from amending the Constitution to accommodate a third term for the president. Secondly, for the first time in its history Frelimo organised open primaries to nominate its presidential candidates. In these primaries not only the party leader's preferred candidates were rejected but the process was also open to independent candidates, against the will of the party leadership. So while elections have a democratising effect, it appears that these events may have positive effects on the party system not only by deepening democratic practice within Frelimo but also by influencing events in other parties.

Election day was peaceful despite the late opening of polling stations, ballot-box stuffing, invalidation of opposition ballot papers and problems with registration books. The final results indicate that Frelimo and its candidate, Filipe 
Jacinto Nyusi, collected a comfortable majority even though this was marred by problems in an estimated $12 \%$ of polling stations. However Dhlakama disputed the election results on the grounds that they were fraudulent. While this was not intended to discount the problems in some of the polling stations, Renamo failed both to make proper use of the improved system for electoral administration, e.g. fraud prevention, and also to present any evidence of the alleged fraud.

Instead of proposing a government of national unity and a caretaker government, Dhlakama moved to propose a bill for provincial self-government. This bill is a political settlement and is not a remedy for alleged electoral fraud. Frelimo has accordingly rejected the Renamo proposal of provincial autarchies on the grounds of unconstitutionality, but has failed to find a mechanism of compromise with Renamo. There are clearly technical problems related to the 2014 election which were not seriously dealt with by the electoral management bodies. But Renamo is also to blame for failing to use the system of transparency it proposed, which could allow for a better understanding of the extent to which fraud accounts for its electoral loss. Mozambique's election fails to be a constructive mechanism for political settlement, mainly because Mozambique's electoral system, although proportional, is a disguised winner-takes-all system. Thus the agenda for the next electoral cycle was set, first to ending military hostilities, and then to drafting legislation that will accommodate agreements comprising the peace deal. It remains impossible for the opposition parties to make proper use of the theoretically improved electoral administration since Frelimo dominates these institutions, resulting in its political dominance of the country.

\section{- REFERENCES}

Carter Center 2014. http://www.cartercenter.org/resources/pdfs/news/pr/ Mozambique-prelim-10-17-14.pdf (acessed on the 2nd of June, 2015).

Da Silva, A 2011, 'at least 13 FIR agents may have died in Maringuè', in Canal de Moçambique. Available at: http://macua.blogs.com/moambique_para_ todos/2011/05/relatos-dos-confrontos-com-homens-da-renamo.html?cid=6 a00d83451e35069e201538e6dbe6b970b

De Brito, L 2009, ‘O Sistema Eleitoral: Uma Dimensão Critica da Representação Política em Moçambique', in L Brito, CN Castel-Branco, S Chichava \& A Francisco (orgs.), Desafios para Moçambique 2010. Maputo: IESE, 17-30.

EISA, 2014, http://www.content.eisa.org.za/pdf/moz2014eom6.pdf)

Frades, A 2013, 'The Government confirms the death of four FIR agents in Canalmoz', Available ate: http://www.canalmoz.co.mz/hoje/24829-maputocanal-canalmoz-mocambique-noticia-nacional-sociedade-html 
Hanlon, J \& Fox 2006, 'Identifying Fraud in Democratic Elections: A Case Study of the 2004 Presidential Elections in Mozambique', Crisis States Research Centre, LSE, Working Paper 8.

http://macua.blogs.com/files/cmc_nr277_final.pdf (accessed on the $4^{\text {th }}$ of June, 2015). Mozambique Political Process Bulletin 2014a, no. 47, 24 September.

Mozambique Political Process Bulletin 2014b, no. 48, 28 September

Mozambique Political Process Bulletin 2014c, no. 55, 13 October

Mozambique Political Process Bulletin 2014d, no. 56, 14 October.

Mozambique Political Process Bulletin 2014e, no. 56, 28 November.

Nuvunga, A \& MA 2010, 'Mozambique's 2009 Elections: Framing Democratic Consolidation in Context', Journal of African Elections, vol. 9, no.1, pp. 34-54.

Nuvunga, A 2005, 'Multiparty Democracy in Mozambique: Strengths, Weaknesses and Challenges', EISA Report, no. 14.

Nuvunga, A 2006, 'Institutional and Technical Capacities in the Organisation of Electoral Governance - Mozambique, in N Aworti \& E Sitoe (eds.), African Perspectives on New Public Management: Implications for Human Resources Training. Shaker, Maastricht.

Nuvunga, A 2012, 'Tendências nas Eleições Municipais de 1998, 2003 e 2008', in B Weimer (ed.), Moçambique: Descentralizar o Centralismo - Economia politica, recursos, resultados, IESE, Maputo.

Nuvunga, A 2014, From the Two-Party to the Dominant-Party System in Mozambique, 1994-2012: Framing Frelimo Party Dominance in Context. Ph.D thesis, International Institute of Social Studies of the Erasmus University Rotterdam.

Rønning, H 2011, 'The Frelimo State', Conference on Legitimacy of Power - Possibilities of Opposition, 30 May-1 June11, Jinja, Uganda. 